\title{
INDONESIAN EFL STUDENTS' PERCEPTIONS ON LEARNING AUTONOMY IN ONLINE LEARNING DELIVERY MODE
}

\author{
Dalilan \\ Faculty of Adab and Humanity, UIN Raden Fatah Palembang, Indonesia \\ (putrada888@gmail.com)
}

\begin{abstract}
The online learning delivery method is increasingly used in the teaching and learning process at universities. This type of learning is relatively new to students, in particular to Indonesian EFL students. Students' learning autonomy in an online learning system is inevitably required. Autonomy in online learning and in offline learning can be differently perceived by the students. This study aimed at revealing EFL students' perception on learning autonomy in an online learning method. A questionnaire was used as the single instrument to obtain data from 35 students of the English Education Study Program of Tarbiyah and Teacher Education Faculty, State Islamic University Raden Fatah Palembang. The study sample was selected using opportunity sampling, and data were analyzed using a simple percentage statistic formula. The study results indicated that the majority of the students perceive online learning as independent learning in which they must have self-learning awareness and motivation, self-learning responsibility, and self-directed and governed learning. They also perceived that they could develop the problem-solving ability, critical thinking, and learning initiative in autonomous online learning. In the context of learning independently in an online learning system, self-time management is also essential to support their learning optimally.
\end{abstract}

Keywords: Learning Autonomy; Online Learning; Perception

First Received:

(September 24, 2021)
Final Proof Received:

(September 29, 2021)

\section{INTRODUCTION}

Becoming a university student today is very challenging. They are faced with the transformation of interaction and instruction due to the COVID-19 pandemic since the beginning of March 2020 (Purwadi et al., 2021). This pandemic until now has been impacting the way Indonesian students carry out their learning. The learning setting changes from the actual classroom learning process to virtual or online learning activities. This change of learning to set requires learners to adjust to new strategies in their learning.

One of the challenges in the learning process felt by Indonesian students nowadays is to be autonomous learners in the online learning delivery method. Learning through an online platform needs learners' independence without being tightly controlled by a lecturer in real classroom instruction. Learning in an online network undoubtedly demands more student learning independence. To be autonomous in this learning setting, 
learners experience two processes at the same time. Students learn to be autonomous and learn how to learn. The phrase "learning how to learn" suggests that the learners themselves personally direct and manage their own learning process. Online learning without face-to-face interaction provides more opportunities for learners to set their own learning independently.

Students who are experiencing online learning need autonomy support (Lee et al., 2015). E-learners are faced with virtually new experiences. Independence in online learning matters for them. In this context, independent learning in online learning situations considerably needs students' self-motivation, self-awareness, self-belief, selflearning responsibility, and self-confidence more than learning in the real classroom (Stack, 2015). In an online learning system, in which students' autonomous learning can occur, distant learners may consider that self-directed learning or self-controlled learning in an online way can motivate them to have more learning responsibility, beliefs, and confidence (Broadbent \& Poon, 2015). Autonomy in learning is not easy to be realized by students who do not get used to independent learning. They are not accustomed to learning how to learn independently. They are continuing to adapt this new teaching and learning methodology (Khan et al., 2020). As in actual classroom instruction in the normal situation before the pandemic, they are very dependent and passive. They tend to depend on their lecturers in planning, monitoring, and evaluating their own learning.

The COVID-19 pandemic has been changing the learning pattern of the students since the beginning of March 2020, when the virus pandemic started spreading in Indonesia. Learning in an online system becomes a new learning approach that makes most students manage or regulate their learning so that they possess positive images of self-regulated learning (Purwadi et al., 2021). Students in all levels of education experience adjustment to this current method of learning. This new learning situation and setting can impact their attitudes (e.g., emotion, beliefs, motivation, and perception) toward learning online.

Knowing how students, particularly EFL students, think of autonomous learning through this Internet-mediated learning approach can be considerably important. Learning autonomy in an online learning setting with its particular characteristics can be positively and negatively perceived by EFL learners. Online learning can be a propitious momentum and opportunity for students to learn independently in this type of distance learning. Some other students probably also find it problematic to learn autonomously in this kind of virtual learning. Many students are likely ready to be independent learners, and many other students feel unprepared to be autonomous. Perhaps, few students are highly motivated to learn with no lecturer sitting or standing in front of them, just like in the real classroom, but it can be a lot of students whose motivation is very low learning without a lecturer's monitoring. In learning in the online system, they may be fully aware of becoming learning director and manager for themselves (Talkowska, 2015). Talkowska 
also emphasized that the use of the Internet can promote autonomous learning outside the classroom in which students can find suitable strategies of learning by themselves. Eventually, having information about EFL students' perception on learning autonomy in the online learning situation is crucial for both students themselves and lecturers. To the lectures, they can plan the best online teaching strategies they can implement, and, to the students, they can well prepare for the best online learning strategies to achieve their learning outcomes as optimal as possible.

Research into students' perception of learning autonomy in Indonesia's online learning context is relatively a new issue, in the sense that this mode of learning in the online system is widely introduced to Indonesian students when classroom interaction was changed into an online learning environment (Padmo et al., 2017). Searching for learning autonomy in the online learning approach, particularly in Indonesian EFL students' online learning autonomy context, needs more attention. Further studies in the area of learning autonomy in the context of online learning delivery mode are necessary (Khotimah et al., 2019). In this case, the study of EFL students' perception of learning autonomy in virtual learning needs more attention. Tuchfah in her undergraduate thesis found out that students had a positive perception of learner autonomy in English language learning but did not link the learning autonomy to online learning through the Internet (Tuchfah, 2019). Lengkanawati studied learner autonomy in the Indonesian EFL settings in the real classroom (Lengkanawati, 2017). Learner autonomy in learning or autonomy in learning is significant to be studied nowadays in the context of online learning. Accordingly, the researcher of this study is anxious and interested in recognizing what EFL students have in their minds regarding learning autonomy in this Internet-mediated learning platform.

This study attempted to reveal information concerning students' perception on online learning independence. Specifically, it aims to investigate Indonesian EFL students' perception on autonomy in learning in online learning system, which almost all education institutions in Indonesia widely implement at the present time.

\section{LITERATURE REVIEW}

\section{Concept of Perception}

Perception is concerned with identifying and interpreting sensory information. In a simple way, perception is defined as beliefs or opinions held by people to respond to information coming to mind (Walter \& Woodford, 2010). Perception is a personal manifestation of how one views the world based on his or her life experience, knowledge, and mental insight. In a broader sense, perception is beliefs or views in judging or evaluating whether something is considered right or wrong, effective or ineffective, and positive or negative (McDonald, 2012). It is the personal opinion of choosing, organizing, and interpreting information to have a clear picture coming to mind (Baliyan \& Moorad, 
2018). Manifestation of perceptions differs depending on self-experiences and the extent of one's understanding of information or reality. In this study, perception constitutes learners' beliefs, opinions, and views concerning autonomous learning in the online learning environment.

\section{Definition of Learning Autonomy}

In the context of learning, autonomy is defined as a capacity to take control of a learner's own learning (Benson, 2001). The learner can take charge of his or her own learning process by making himself or herself capable of making his or her own decision in determining learning objectives, defining the contents and his progress, selecting methods and techniques, monitoring the procedures of acquisition, and evaluating what has been acquired (Lengkanawati, 2017). Autonomy in learning is when a learner is totally accountable for all the decisions concerned with his or her own learning and the implementation of the decisions.

This definition impresses that learning autonomy is the self-controlled capability in one's own learning, particularly students' own learning. Central to the concept above is that learning autonomy is a self-learning management activity in an attempt to find out the solution to the learners' learning problems. Learning autonomy suggests a consideration of two important pillars, responsibility and self-awareness (Ustunluaglu, 2009), that must be possessed by a learner to organize and manage their learning decisions such as determining learning objectives, defining learning contents and progress, choosing learning methods and techniques, monitoring the procedures of acquisition during learning process, and evaluating learning outcomes that have been acquired.

Learning autonomy is basically self-directed learning. In the process of learning wherever they are, either in an actual classroom or virtual classroom, students make the diagnosis of their own needs of learning, according to their, own goals, identifying the variety of educational resources and planning strategies to use these features, evaluating their own learning and having validated evaluation. Learning autonomy in the online delivery method is a student-centered independent learning mediated by the Internet. Students must consciously regulate their learning awareness, motivation, and responsibility without being controlled and monitored by lecturers or teachers to run learning plans and processes.

\section{Benefits of Learning Autonomy for Students}

Not all students are independent learners. But they can be independent by making them accustomed to their own authority in learning. Students should be adjusted and exposed to a learning situation in which they practice learning autonomy. Autonomy in learning is and must be a long life habit both inside and outside the actual classroom. Learning autonomy must be seen as a positive learning habit that is beneficial for students. 
Autonomy in learning leads students to be more capable of making decisions about what and how they learn (Binn, 2020). It can increase student's confidence and motivation, bring students a greater awareness of their limitations and their ability to manage them, understand and set their goals better, and identify helpful learning resources.

Learning autonomy practices students' critical thinking skills (Najeeb, 2012). Autonomous learning is identical to independent thinking, and this process train students to think critically of when they plan, monitor, and evaluate their learning. Autonomously continuing learning opens the opportunity to make students become people who have the mentality of accountability for what they have to do and doing it without anyone telling them to do it (Najeeb, 2012). Exposure to autonomous learning will develop students' critical thinking skills, self-confidence, self-encouragement, self-learning initiative, and self-regulated learning ability.

\section{Online Learning}

We are now entering an era where streaming video, video and audio conferencing, and virtual worlds are readily available for educational use (Anderson \& Elloumi, 2004). With these technological gifts, we come to the world of online learning.

Online learning in the advanced technology era nowadays is a very popular term in the education world. Online learning is sometimes understood as e-learning, virtual learning, and distant learning. Online learning refers to instructional environments supported by the Internet. Comprising a wide variety of programs that use the Internet within and beyond school walls to provide access to instructional materials and facilitate interaction among teachers and students (Bakia et al., 2012). They point out that there are two approaches to online learning: fully online learning and blended learning with face-toface interactions.

Fully online learning is a form of distance education in which all instruction and assessment are carried out using online, Internet-based delivery. In this approach, a teacher leads the instruction himself and provides instructional resources without the teacher's presence, and it includes instructional environments accessed exclusively through the Internet. Blended learning (also called hybrid learning) allows students to receive significant portions of instruction through face-to-face and online means (Bakia et al., 2012). Both fully and blended online learning are types of Internet-mediated learning in which teachers and students interact from different rooms supported by online media such as What's App, zoom meet, YouTube, e-mail, Google classroom, or any other media created by education institutions.

\section{Benefits of Online Learning for Students}

Online learning as the main delivery method used by educational institutions these days is increasing. Educational institutions are moving toward the use of the Internet for 
delivery, both on campus and at a distance (Simmons, 2012). Online learning as distant learning serves benefits for students. Ally outlined the benefits of online learning for students as follows (Ally, 2004):

1. Students can access the online learning materials at any time,

2. Students can use the Internet to access-up-to-date and relevant learning materials,

3. Students can communicate with experts in the field in which they are studying,

4. Students' learning can be situated because they can compete in online courses while working in their own space,

5. Students can contextualize the learning.

For students who intend and are serious about being independent in learning, the online learning situation is opened to them to explore their spirit, knowledge, and skill in designing their own learning by using the Internet resources for relevant, expanded, and up-to-date learning materials.

\section{Students' Autonomy in Online Learning}

In online learning, the actual presence of students and a teacher is replaced by technological mediation. Online learning autonomy is marked by the physical separation between students and a teacher. Therefore, online learning as distance learning requires learners' autonomy in the sense that more portions of students' roles and responsibilities are needed without the direct presence of a teacher. Students play their own role as selflearning controllers and managers (Talkowska, 2015). Online learning provides autonomous learning, which is student-centered learning whose experiences serve as a resource for independent students to be considered responsible managers for the learning process.

Online learning is conducted in the virtual network. In the virtual learning environment, students' independent learning is dealt with developing the ability to determine their own learning activities, to access the content whenever and as many times as necessary in the pursuit of understanding of what arouses interest and desire to learn (Gottardi, 2015).

Concepts, principles, and characteristics of learning autonomy were theoretically developed decades ago. These theories have been used to foster autonomy in the context of learning in institutional educations, particularly in a classroom learning and teaching process. The theories are basically and principally applicable to the context of learning autonomy in online learning systems. In its broad sense, autonomy in learning is more practical and flexible to be implemented by the students in online learning events in which learning materials are easily accessible and unlimited available. 


\section{METHOD}

This is a quantitative study aimed at seeking information about students' perception on learning autonomy. The data concerning their perception were obtained by administering a questionnaire to the respondents. A questionnaire of 17 statements was used as a single instrument to collect data on EFL students' perception. A questionnaire is an instrument used to elicit information about the respondents' attitudinal perception. One type of data produced by a questionnaire is concerned with what people think, covering attitudes, opinions, beliefs, and values (Dornyei, 2007). Seventeen statements for data production in this research were based on theoretical concepts of autonomy in online learning. The concepts explored include important accounts in learning autonomy such as self-governing, self-motivation, self-responsibility, self-awareness, self-control, self-time management, self-confidence, self-problem solving, self-implementation of own knowledge and skill, self-critical thinking, and self-learning initiatives.

The questionnaire used the Likert's scale consisting of 4 responses: strongly disagree, disagree, strongly agree, agree. Each response option is assigned for scoring purposes (e.g. "strongly disagree"= 1, "disagree"= 2, "strongly agree"= 3, "agree"=4). The statements were in the Indonesian language in favor of students' ease of understanding and thinking of each option. The students were instructed to choose one of the options which depicted what they perceived or thought.

The questionnaire was distributed to the respondents of the study consisting of 35 sixth students of the English Education Study Program, Faculty of Tarbiyah and Teacher Training, State Islamic University Raden Fatah Palembang. These sample students were selected by using the opportunity sampling technique. Opportunity or convenience sampling was used for this study because of some practical criteria such as availability and accessibility (Dornyei, 2010). In addition, another criterion that is central for this study is that the sample students have experienced online learning as the university policy enforced at the beginning of last March due to the COVID-19 pandemic.

In terms of data analysis, a simple analytical statistics using the following formula was used:

$$
\text { Answers }(\%)=\frac{\text { Amount of students' answer }}{\text { Total number of the students }} \times 100
$$

The steps of data analysis cover:

1. Calculating students' answers from each item of the questionnaire,

2. Comparing with the total participants to obtain the percentage of each item,

3. Calculating the average percentage of each option. 


\section{RESULTS AND DISCUSSION}

\section{Results}

\section{The EFL students' perception on online learning autonomy}

The discussion that follows presents the results of students' responses to the statements in the questionnaire. The questionnaire was used to gain information about what they perceived or thought of fundamental ideas in online learning autonomy concerning self-governing, self-motivation, self-responsibility, self-awareness, self-control, self-time management, self-confidence, self-problem solving, self-implementation of own knowledge and skill, self-critical thinking, and self-learning initiatives. The results indicated that most students perceived learning autonomy in line with basic ideas explained in theoretical concepts. The overall percentages of students' perception are presented in the following table.

Table 1.

The Results of EFL students' Perception

\begin{tabular}{|c|c|c|c|c|}
\hline Statement & $\begin{array}{l}\text { Strongly } \\
\text { disagree }\end{array}$ & disagree & $\begin{array}{l}\text { Strongly } \\
\text { agree }\end{array}$ & Agree \\
\hline $\begin{array}{l}\text { 1. Learning through an online system is the } \\
\text { way of independent learning }\end{array}$ & $17.14 \%$ & - & $65.71 \%$ & $14.28 \%$ \\
\hline $\begin{array}{l}\text { 2. In the learning process through online } \\
\text { way, I become a self-learning organizer. }\end{array}$ & $5.71 \%$ & $4 \%$ & $60 \%$ & $22.85 \%$ \\
\hline $\begin{array}{l}\text { 3. Learning with an online system can } \\
\text { strengthen my self-motivation in } \\
\text { learning. }\end{array}$ & $5.71 \%$ & $22.85 \%$ & $57,14 \%$ & $14.25 \%$ \\
\hline $\begin{array}{l}\text { 4. In the situation of online learning, I take } \\
\text { charge of own learning responsibility. }\end{array}$ & $14.28 \%$ & $8.57 \%$ & $54.28 \%$ & $14.28 \%$ \\
\hline $\begin{array}{l}\text { 5. Becoming an autonomous or an } \\
\text { independent learner provides learning } \\
\text { experience of self-governing without } \\
\text { being controlled by a lecturer as in the } \\
\text { real classroom. }\end{array}$ & $5.71 \%$ & $14.28 \%$ & $60 \%$ & $17.14 \%$ \\
\hline $\begin{array}{l}\text { 6. I can make use of time wisely when } \\
\text { learning in an online way. }\end{array}$ & $8.57 \%$ & $17.14 \%$ & $60 \%$ & $14.28 \%$ \\
\hline $\begin{array}{l}\text { 7. Learning in an online situation needs } \\
\text { strong learning awareness. }\end{array}$ & $5.71 \%$ & $5.71 \%$ & $37.14 \%$ & $54.28 \%$ \\
\hline $\begin{array}{l}\text { 8. Independent learning online needs } \\
\text { bigger responsibility than learning in the } \\
\text { classroom watched by a lecturer directly. }\end{array}$ & $8.57 \%$ & $11.42 \%$ & $60 \%$ & $20 \%$ \\
\hline $\begin{array}{l}\text { 9. By learning independently through } \\
\text { online system, I can develop and practice } \\
\text { my responsibility for own learning } \\
\text { performance. }\end{array}$ & $2.85 \%$ & $14.28 \%$ & $74.28 \%$ & $11.42 \%$ \\
\hline
\end{tabular}




\begin{tabular}{lllll}
$\begin{array}{l}\text { 10. During my online independent learning, } \\
\text { I need cooperation with my classmates }\end{array}$ & $2.85 \%$ & $5.71 \%$ & $42.85 \%$ & $48.57 \%$ \\
\hline $\begin{array}{l}\text { 11. I have self-confidence in completing my } \\
\text { subject tasks independently in online } \\
\text { learning situation. }\end{array}$ & $2.85 \%$ & $14.28 \%$ & $54.28 \%$ & $31.42 \%$ \\
\hline $\begin{array}{l}\text { 12. Learning in an autonomous way practice } \\
\text { my learning problem-solving skill. }\end{array}$ & & & & \\
\hline $\begin{array}{l}\text { 13. In online independent learning, I feel } \\
\text { free in applying knowledge and skill of } \\
\text { my learning. }\end{array}$ & $5.71 \%$ & $11.42 \%$ & $57.14 \%$ & $20 \%$ \\
\hline $\begin{array}{l}\text { 14. During the scheduled time of online } \\
\text { learning, I rely on my friends' help in } \\
\text { doing task from a lecturer. }\end{array}$ & $25.71 \%$ & $40 \%$ & $31.42 \%$ \\
\hline $\begin{array}{l}\text { 15. Learning independently of the online } \\
\text { system can practice my critical thinking } \\
\text { in planning, implementing, and } \\
\text { evaluating my own learning. }\end{array}$ & $2.85 \%$ & $20 \%$ & $54.28 \%$ & $22.85 \%$ \\
\hline $\begin{array}{l}\text { 16. Becoming an autonomous learner in } \\
\text { online setting, I have initiative in } \\
\text { planning and implementing my learning } \\
\text { activity. }\end{array}$ & & & & \\
\hline $\begin{array}{l}\text { 17. I prefer independent learning in online } \\
\text { system to independent learning in offline } \\
\text { setting (direct interaction in the real } \\
\text { class). }\end{array}$ & $25.71 \%$ & $40 \%$ & $20 \%$ & $14.28 \%$ \\
\hline
\end{tabular}

From table 1, it can be seen that most students' options of agree are above $50 \%$. Only 4 of 17 agree options is below 50\% occurred in statements 7, 10, 14, and 17. Meanwhile, the options strongly disagree, disagree, and strongly agree far below $50 \%$. Most statements were responded to by the students. There were only two options that were not responded to; no student responded disagree to statement no. 1 and strongly disagree to statement no. 12. The detailed average of percentages of the students' responses are presented below:

$\begin{array}{ll}\text { Strongly Disagree } & : 8.40 \% \\ \text { Disagree } & : 15.19 \% \\ \text { Agree } & : 54.78 \% \\ \text { Strongly Agree } & : 20.66 \%\end{array}$

From these quantitative percentage results, it can be said that more than half the students under the study had a positive perception of learning autonomy through an online learning system. They fairly agreed with the characteristics of learning autonomy in this mode of learning to set. It is to say that they support characteristics such as selfgoverning, self-motivation, self-responsibility, self-awareness, self-control, self-time 
management, self-confidence, self-problem solving, self-implementation of own knowledge and skill, self-critical thinking, and self-learning initiatives. Yet, from the calculation of percentages, it can also be stated that not all participants of the study (40\%) completely agree with autonomous learning in online learning interaction and instruction.

Based on the results of percentage calculation, it also indicated that the highest percentage is $74,28 \%$, which occurred in statement number 9 , in which the participants agreed with self-responsibility as the essential authority they must have in autonomous learning during the online learning event. Self-responsibility in learning is the essential authority the students themselves must possess to accomplish their duty without blaming other people if it cannot be completed.

It is also interesting to state from the finding that self-learning awareness (statement 7 ) is the highest percentage of the whole statements (54.28\%). From this percentage, it can be said that the participants thought the importance of awareness in learning autonomously. They most probably realized that self-learning awareness is essential to embark on running independent learning, particularly in the context of online learning.

Practicing self-responsibility (74.28\%), practicing ability of learning problem solving (71.42\%), and having initiatives in planning and implementing own learning activity $(71.42 \%)$ were considered as the fairly important benefits in developing learning autonomy through the online learning experience.

\section{Discussion}

The data of this research clearly indicate that the respondents thought that online learning requires self-independence. This confirms the results of the previous studies that positive perception students consider online learning as motivational learning to make individuals more independent in learning (Purwadi et al., 2021). The information given by the respondents demonstrated that they must have high learning awareness and motivation in adjusting to the Internet-mediated learning situation so that they can be autonomous learners. There is a close relationship between autonomy in learning and motivation in learning in the Internet-assisted learning context (Liu, 2015). Learning through the Internet approach can trigger students' motivation as one of the key components of autonomous learning (Beatty, 2003). The respondents consciously perceived that they have to organize own learning in an online learning way. The most significant advantage of undergoing online system learning perceived by the respondents is improving and practicing their own learning responsibility. This advantage confirms research finding that learning autonomy leads to the students' capacity to take responsibility for the whole learning process (Bravo, 2017).

The data also clearly showed that autonomy in online learning plays an important role in triggering students' initiative in planning and implementing learning activities independently. In line with this, the study carried out by (Khotimah et al., 2019) 
demonstrated that autonomous learning is a kind of initiative learning. Autonomous learning is self-directed learning. It is a process during which a student assumes that planning, implementing, and evaluating the learning process is primary responsibility (Song \& Hill, 2007). It provides further support for self-planning in preparing and implementing learning activities (Najeeb, 2012). The fairly significant data provided by the respondents is that they must be accountable to be autonomous in learning without the lecturer's control and monitor as in the real classroom learning. Liu pointed out that autonomy allows students to undergo being self-determined rather than being controlled (Liu, 2015). The respondents were also found to be able to practice solving learning problems in an online learning atmosphere.

The important implication of this study for supporting EFL students' learning autonomy in online learning in the pandemic era nowadays derives from the finding that the virtual learning process might not be effective and optimal to gain expected students learning outcomes. Online learning delivery mode may not be interactive and interesting for the students to follow in the long run. This mode of learning should include more support and encouragement from the lecturers to promote students' autonomy in selfdirected learning. The lecturers must take into consideration the limitation and obstacles of online learning at the students' party. The study provides information about students' preference for actual classroom interaction and instruction. Further research into what appropriate picture of online learning autonomy is useful and very informative.

\section{CONCLUSION}

Autonomy in learning was perceived as independent learning by the majority of the participants of the study. The students had the perception that the online learning setting required self-independence in carrying out their learning process. The first thing they perceived they must have was self-learning awareness. During the implementation of scheduled online classes, self-responsibility in learning was essential to achieve a good learning performance. They thought that they could develop the ability to solve problems and learning initiatives in autonomous online learning. In learning independently in an online learning system, self-organizing and governing and self-time management is essential to support their learning optimally. This study used a single data collection instrument and data analysis. These procedures are very simple to help elicit muchcomplicated information about learning autonomy in an online learning setting. Further research is suggested to use more than one data collection method and way of data analysis so that much more information about students' online learning autonomy in online learning conditions can be revealed. In addition, research into this issue must be encouraged because schools and universities will widely implement online learning. 


\section{REFERENCES}

Ally, M. (2004). Foundations of Educational Theory for Online Learning. In T. Anderson \& F. Elloumi (Eds.), Theory and Practice of Online Learning. Athabasca: Athabasca University.

Bakia, M., Shear, L., Toyama, Y., \& Lassete, A. (2012). Understanding the Implications of Online Learning for Educational Productivity. Center for Technology in Learning SRI International. https://tech.ed.gov/files/2013/10/implications-online-learning.pdf

Baliyan, S., \& Moorad, F. (2018). Teaching Effectiveness in Private Higher Education Institutions in Botswana: Analysis of Students' Perceptions. International Journal of Higher Education, 7(3), 143-155. https://doi.org/10.5430/ijhe.v7n3p143

Beatty, K. (2003). Teaching and Researching Computer-Assisted Language Learning. London: Pearson Education.

Benson, P. (2001). Teaching and Researching Autonomy in Language Learning. London: Longman.

Binn, K. (2020). The Benefits of Autonomous Learning. http://somervilleacademy.com/thebenefits-of-autonomous-learning/

Bravo, J. C. (2017). Motivation and Autonomy in Learning English as Foreign Language: A Case Study of Ecuadorian College Students. English Language Teaching, 10(2. 10.5539/elt.v10n2p100

Broadbent, J., \& Poon, W. (2015). Self-Regulated Learning Strategies \& Academic Achievement in Online Higher Education Learning Environments: A Systematic Review. The Internet and Higher Education, 27, 1-13. https://doi.org/10.1016/j.iheduc.2015.04.007

Dornyei, Z. (2007). Research Methods in Applied Linguistics. Oxford: Oxford University Press.

Dornyei, Z. (2010). Questionnaires in Second Language Research: Construction, Administration, and Processing. London: Routledge.

Gottardi, M. de L. (2015). Autonomy in the Learning Process at a Distance: The Competence to be Developed by the Student. Associação Brasileira de Educação a Distância, 14, 108-110.

Khan, M. A., Vivek, V., Nabi, M. K., Khojah, M., \& Tahir, M. (2020). Students' Perception towards E-Learning during COVID-19 Pandemic in India: An Empirical Study. Sustainability, 13(1), 1-14. https://doi.org/10.3390/su13010057

Khotimah, K., Widiati, U., Mustofa, M., \& Ubaidillah, M. F. (2019). Autonomous English learning: Teachers' and students' perceptions. Indonesian Journal of Applied Linguistics, 9(2), 371-381. https://doi.org/10.17509/ijal.v9i2.20234

Lee, E., Pate, J. A., \& Cozart, D. (2015). Autonomy Support for Online Students. TechTrends, 59(4), 54-61. https://doi.org/10.1007/s11528-015-0871-9 
Dalilan, Indonesian EFL Students' Perception on Learning Autonomy in Online Learning ...

Lengkanawati, N. S. (2017). Learner Autonomy in The Indonesian EFL Settings. Indonesian Journal of Applied Linguistics, Vol. 6 No. 2, 222-231.

Liu, H. ju. (2015). Learner Autonomy: The Role of Motivation in Foreign Language Learning. Journal of Language Teaching and Research, Vol. 6, No. 6, 1165-1174.

McDonald, S. M. (2012). Perception: A Concept Analysis. International Journal of Nursing Knowledge, 23(1), 2-9. https://doi.org/10.1111/j.2047-3095.2011.01198.x

Najeeb, S. (2013). Learner Autonomy in Language Learning. Procedia - Social and Behavioral Sciences, 70, 1238-1242. doi: 10.1016/j.sbspro.2013.01.183

Padmo, D., Belawati, T., Idrus, O., \& Ardiasih, L. S. (2017). The State of Practice of Mobile Learning in Universitas Terbuka Indonesia. In A. Murphy, H. Farley, L. E. Dyson, \& H. Jones (Eds.), Mobile Learning in Higher Education in the Asia-Pacific Region 40, 173190. Springer Singapore. https://doi.org/10.1007/978-981-10-4944-6_9

Purwadi, Saputra*, W. N. E., Wahyudi, A., Supriyanto, A., Muyana, S., Rohmadheny, P. S., ... Kurniawan, S. J. (2021). Student Perceptions of Online Learning during the COVID19 Pandemic in Indonesia: A Study of Phenomenology. European Journal of Educational Research, 10(3), 1515-1528.

Simmons, D. E. (2012). The Forum Report: E-Learning Adoption Rates and Barriers. New York: McGraw-Hill.

Song, L., \& Hill, J. (2007). A Conceptual Model for Understanding Self-Directed Learning in Online Environments. Journal of Interactive Online Learning, 6(1), 27-42.

Stack, S. (2015). Learning Outcomes in an Online vs. Traditional Course. International Journal for the Scholarship of Teaching and Learning, 9(1), 1-18. https://doi.org/10.20429/ijsotl.2015.090105

Wojciechowska, A. T. (2015). The Use of the Internet in Developing Learner's Autonomy. World Scientific News, 8, 54-81.

Tuchfah, F. N. (2019). Teachers' and Students' Perception of Learner Autonomy in Language Learning at SMAN I Gedangan Sidoarjo [Undergraduate Thesis, UIN Sunan Ampel Surabaya].

Ustunluaglu, E. (2009). Autonomy in Language Learning: Do Students Take Responsibility for Their Learning? Journal of Theory and Practice in Education, 5 (2), 148-169.

Walter, E., \& Woodford, K. (2010). Cambridge Advanced Learner's Dictionary. Cambridge: Cambridge University Press. 